YIAMT-377

$\mathrm{Y}-12$
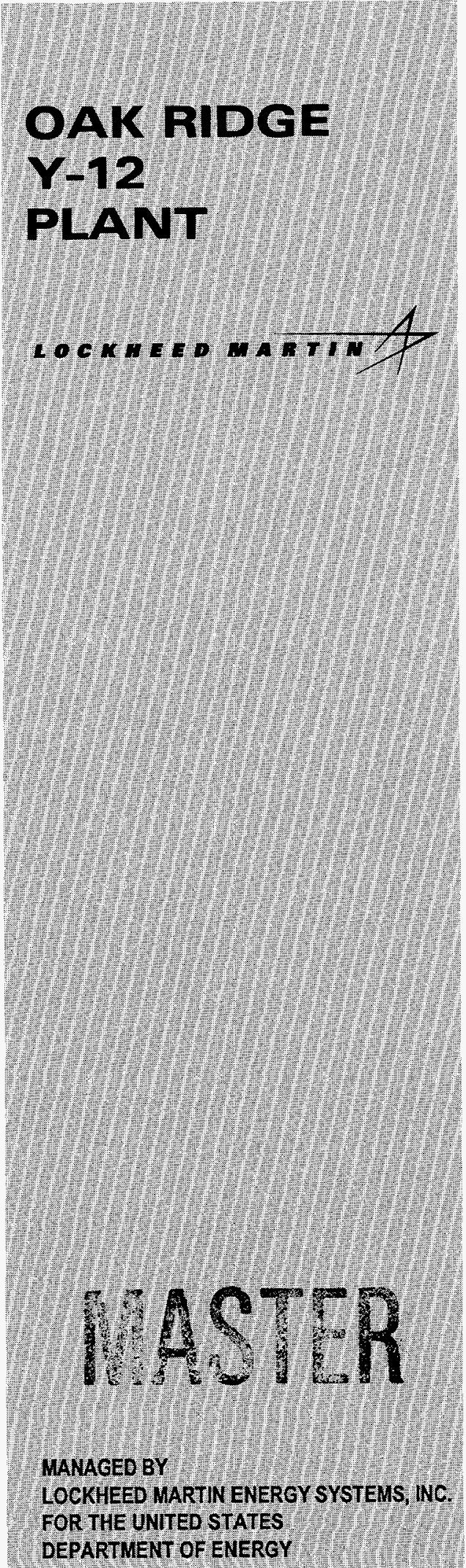

FOR THE UNITED STATES

DEPARTMENT OF ENERGY

\author{
CRADA Final Report \\ for \\ CRADA Number Y-1293-0185
}

\section{PROCESS MODELING AND MACHINING OPERATIONS DEVELOPMENT}

RECEIVED

J. B. Arnold

K. L. Kruse

P. K. Stone

JAII 031997

OST.I

Lockheed Martin Energy Systems, Inc.

K. A. Anderson

Ferro Corp., Diamonite Products Business Unit (formerly W. R. Grace, the original CRADA partner)

September 16, 1996

Approved for Public Release; distribution is unlimited.

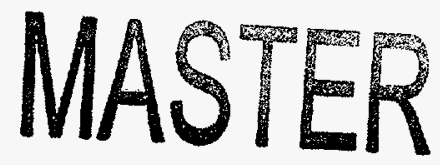

Prepared by the

Oak Ridge Y-12 Plant managed by

LOCKHEED MARTIN ENERGY SYSTEMS, INC. for the

U.S. DEPARTMENT OF ENERGY under contract DE-AC05-84OR21400

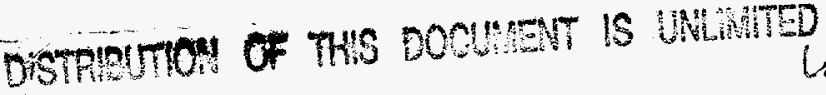




\section{DISCLAIMER}

This report was prepared as an account of work sponsored by an agency of the United States Government. Neither the United States Government nor any agency thereof, nor any of their employees, makes any warranty, express or implied, or assumes any legal liability or responsibility for the accuracy, completeness, or usefulness of any information, apparatus, product, or process disclosed, or represents that its use would not infringe privately owned rights. Reference herein to any specific commercial product, process, or service by trade name, trademark, manufacturer, or otherwise, does not necessarily constitute or imply its endorsement, recommendation, or favoring by the United States Government or any agency thereof. The views and opinions of authors expressed herein do not necessarily state or reflect those of the United States Government or any agency thereof. 


\title{
CRADA Y-1293-0185 Final Report
}

\begin{abstract}
Lockheed Martin Energy Systems, Inc. and Ferro Corporation (formerly W. R. Grace, the original CRADA partner) have collaborated on an effort to develop techniques and processes for the cost-effective machining of ceramic components. The purpose of this effort was to develop a machining model, and grinding equipment machines and techniques for fabricating precision ceramic components.

This project was designed to support Department of Energy (DOE) technical needs in manufacturing hard materials as well as enabling U.S. industry to maintain a position of leadership in the production of precision grinding machines and the machining of structural ceramic components.

\section{CRADA Objective}

The objective of this CRADA was to develop improved processes for fabrication products such as highly configured cylindrical components that require precision machining after sintering. Energy Systems' materials technology expertise and proficiency in precision machining and inspection, in-process control, process modeling and process parameter sensing were to be combined with Ferro's experience in materials processing and ceramic production capabilities to achieve this objective.

\section{Project Results and DOE benefits}

It was with regret that Lockheed Martin Energy Systems had to terminate this CRADA. Oak Ridge Y-12 Plant Program Management determined, as phase one of the CRADA was nearing completion, that their programmatic needs had shifted regarding the CRADA Statement of Work. Consequently, due to scarce funding the CRADA could no longer be supported. But, before the CRADA was terminated several CRADA related activities were conducted. A summary of these activities were prepared by the principal Investigator and documented in a report Y/NA-1797. Various CRADA activities relating to several topics were described, namely: Minimization of Post-Firing/Sintering Material Envelope, Enhanced Dimensional Inspection Capability, and Diamond Grinding Capability Evaluation. Future actives for each of these topics were also prepared in addition to project milestones. A copy of this report is attached.
\end{abstract}

Even though this CRADA was terminated in an early stage, it provided an opportunity to evaluate Energy Systems' precision ceramic production capability. A thorough computer modeling study was done at the Oak Ridge National Laboratory to predict the non-newtonian viscosity behavior of ceramic slurries. Understanding behavior of ceramic slurries is essential to successfully fabricating precision ceramic components by an injection molding process. The effects of the firing/sintering process on the ceramic material was also investigated. How the ceramic shrinks, and how support methods contribute to part distortion during the firing/sintering process were studied (see report Y/NA-1798). Energy Systems also took the opportunity to evaluate its diamond grinding capability and to enhanced its dimensional inspection capability.

\section{Inventions}

There were no inventions developed or reported in the course of this study.

\section{Commercialization Possibilities}

Due to curtailment of this CRADA in the process analysis phase (Phase one), no commercialization possibilities exist.

Future Collaboration

There are no plans for future collaborations. 
DISCLAIMER

Portions of this document may be illegible in electronic image products. Images are produced from the best available original document. 


\section{Conclusions}

Knowledge needed to produce precision ceramic components increased significantly as a direct result of this CRADA. Energy Systems gained a better understanding of 1) the behavior of ceramic slurries during an injection molding process, 2) the Y-12 Plant's ability to diamond grind precision ceramic components, 3) the Y-12 Plant's ability to inspect ceramic components, 4) the degree of shrinkage that occurs during the firing/sintering process, and 5) the effects of various support methods on distortion of the ceramic components that occur during the firing/sintering process. This gained knowledge will prove to be a significant advantage to Energy Systems and to its' CRADA partner in future efforts to economically fabricate precision ceramic components. 


\section{Distribution:}

J. B. Arnold, MS-8204, 9998

W. E. Barkman, MS-8068, 9201-3

K. L. Kruse, MS-6415, 6011

P. K. Stone, MS-8157, 9201-5N

J. E. Ferguson, MS-8242, 701SCA

G. W. Joe, MS-8084, 9203

A. K. Lee/DOE-OSTI, MS-8175, 9983-30 (2 copies)

DOE Office of Patent Counsel, FOB

Y-12 Central Files, MS-8169, 9711-5

Ferro Corporation, Diamonite Products

453 W. McConkey Street, Shreve, Ohio 44676

K. A. Anderson (5 copies) 